\title{
INTERACTION OF SALINITY AND PHYTOHORMONES ON WHEAT PHOTOSYNTHETIC TRAITS AND MEMBRANE STABILITY
}

\author{
ARMAN PAZUKI ${ }^{1}$, MOHAMMAD SEDGHI ${ }^{2}$, FATEMEH AFLAKI ${ }^{2 *}$ \\ ${ }^{1}$ University of Guilan, Rasht \\ ${ }^{2}$ University of Mohaghegh Ardabili, Ardabil
}

PAZUKI, A. - SEDGHI, M. - AFLAKI, F.: Interaction of salinity and phytohormones on wheat photosynthetic traits and membrane stability. Agriculture (Pol'nohospodárstvo), vol. 59, 2013, no. 1, pp. 33-41.

To evaluate phytohormones effects on stomatal conductance, chlorophyll fluorescence, membrane stability, relative water content and chlorophyll content under salinity, a factorial experiment with 4 replicates was conducted. Treatments were salinity $(0,3.5$ and $7 \mathrm{dS} / \mathrm{m})$, phytohormones (control, gibberellic acid and abscisic acid) and wheat cultivars (Gascogen, Zagros, and Kuhdasht). Results showed that a high level of salinity increased chlorophyll fluorescence and relative water content, while membrane stability, chlorophyll content, and stomatal conductance were decreased. Abscisic acid treatment had more effective role in membrane stability.

\begin{abstract}
Although membrane stability was much more under gibberellic acid treatment, restoration of membrane stability was considerable under abscisic acid treatment for Gascogen and Kuhdasht cultivars. Spraying of gibberellic acid induced the highest chlorophyll content in the three salinity levels and all of the cultivars. The maximum amount of stomatal conductance was achieved under gibberellic acid treatment. Abscisic acid caused less chlorophyll fluorescence in comparison to gibberellic acid. About relative water content, abscisic acid was effective in high salinity levels so that it caused stomatal closure, which reduced water loss and maintained turgor in plants.
\end{abstract}

Key words: Triticum aestivum, $\mathrm{NaCl}$, gibberellic acid, abscisic acid, chlorophyll fluorescence, stomatal conductance

Salinity is one of the major abiotic stresses affecting plant growth, development and productivity (Rahnama \& Ebrahimzadeh 2004). Salinity is a complex environmental constraint that presents two main components: i) osmotic component due to decrease in the external osmotic potential of the soil solution and ii) ionic component linked to the accumulation of ions which become toxic at high concentrations (mainly $\mathrm{Na}^{+}$and $\mathrm{Cl}^{-}$) (El-Bassiouny \& Bekheta 2004). It is estimated that over 800 million hectares of land in the world are affected by both salinity and sodicity (Munns 2005). Plants exposed to salt stress must undergo changes in their metabolism in order to survive in the deleterious condition of the stress (Rahnama \& Ebrahimzadeh
2004). These changes include stomatal conductance (SC), photosynthetic efficiency, water and nutrients availability (Munns \& Termaat 1986). Chlorophyll content (CC), relative water content (RWC) and SC are affected by increasing salinity (Adnan Shahid et al. 2008).

RWC represents a useful indicator of the state of plant water balance, because it expresses the absolute amount of water, which plant requires reaching full saturation (González \& González-Vilar 2001). Leaf RWC is a useful trait for selection of tolerant plants in saline condition (Schonfeld et al. 1988) and is significantly reduced under salinity stress (El-Tayeb 2005). Furthermore, salinity stress also reduces RWC in sensitive wheat cultivars seedlings (Aldesuquy \& Gaber 1993). 
Chlorophyll (Chl) is one of the most important pigments, and is responsible for green colour in plants. Changes in photosynthetic parameters could potentially be used as a screening method for salinity tolerance in plants, because more tolerant cultivars are expected to exhibit less disturbances in photosynthetic processes (Belkhodja et al. 1999). Generally, Chl content is reduced under salinity conditions (Iqbal et al. 2006).

One of the leading parameters for the estimation of salinity stress effects is chlorophyll fluorescence (CF). $\mathrm{CF}$ is a subtle reflection of primary reactions of photosynthesis (Sayed 2003). The ratio of $F_{v} / F_{m}$ is proportional in order to show maximum amount of photosystem II (PSII), and this ratio is sensitive to environmental changes (Sayed 2003). Krishnaraj et al. (1993) used measurement of CF for screening of tolerant wheat genotypes (Krishnaraj et al. 1993). Various stress conditions may reduce the rate of photosynthesis, and disturb the light-driven photosynthetic electron transport via CF fluorescence (Allahverdiev et al. 1998). The inverse relationship between in vivo $\mathrm{CF}$ and photosynthetic activity can be used to study the potential photosynthetic activity of leaves and detect stress effects on green plants. There are several parameters of the in vivo $\mathrm{CF}$ which can be applied for detecting stress and damages to the photosynthetic apparatus. Variable fluorescence $\left(F_{v}\right)$ and initial fluorescence $\left(F_{o}\right)$ ratio are two of these parameters, and they show the efficiency of photosynthesis (Allahverdiev et al. 1998).

The decline in productivity in many plant species subjected to excess salinity is often associated with a reduction in photosynthetic capacity (Belkhodja et al. 1999). The reduction in photosynthetic capacity due to salt stress is associated with reduced SC (Belkhodja et al. 1999). Measurement of cell membrane stability (CMS) has often been used for screening for drought and salinity tolerance in various plants such as sorghum, maize, rice and wheat (Jyothsnakumari et al. 2009). The decreased gibberellic acid $\left(\mathrm{GA}_{3}\right)$ and increased abscisic acid (ABA) contents were reported in salt-stressed plants, which led to the suggestion that salt stress induces changes in RWC and membrane permeability (Kaya et al. 2009). Therefore, an alternative strategy to ameliorate salt stress could be exogenous application of plant growth regulators (Levent Tuna et al. 2008). So, focusing on using of phytohormones such as $\mathrm{GA}_{3}$ (which has important effects on regulation of plant reaction to environment and control of some induced genes in stress condition) is necessary (Nagvi 1999). It has been reported that $\mathrm{GA}_{3}$ treatment reduces the adverse effects of salt stress (Chakrabarti \& Mukherji 2003). Phytohormones have also a control role in RWC and membrane permeability (Kaya et al. 2009). It was found that $\mathrm{GA}_{3}$ increases plant growth and pigment content of salinized plants (Aldesuquy \& Gaber 1993). Prakash and Prathapasenan (1990) observed a significant decrease in the levels of gibberellins and cytokinins and an abrupt rise in ABA content in salt-stressed plants (Prakash \& Prathapasenan 1990). ABA has an important function in the ability of rice cultivars to tolerate conditions of stress (Abdel-Haleem \& Tanimoto 2008), so ABA spraying increases expression of numerous reactive genes in salt-stressed rice cultivars (Gupta et al. 1998).

Wheat (Triticum aestivum L.) is one of the most important crops in Iran and throughout the world, which has a special importance in human nutrition (Esfandiari et al. 2007). Thus, this experiment was carried out to evaluate the effects of $\mathrm{ABA}$ and $\mathrm{GA}_{3}$ on some physiological traits of wheat cultivars including membrane stability (MS), chlorophyll content (CC), chlorophyll fluorescence (CF), stomatal conductance (SC), relative water content (RWC) under saline conditions in order to evaluate inhibitory or stimulatory effects and importance of the hormones on above-mentioned parameters in the three Iranian indigenous wheat cultivars in saline conditions.

\section{MATERIALS AND METHODS}

This study was carried out using a factorial experiment based on a completely randomized design with 4 replicates in a greenhouse at The University of Mohaghegh Ardabili, Ardabil, Iran. Treatments were salinity [Control : $0\left(\mathrm{Ctrl}_{\mathrm{s}}\right), 3.5$ and $7 \mathrm{dS} / \mathrm{m}$, phytohormones $\left(\mathrm{GA}_{3}: 50 \mathrm{mg} / \mathrm{l}, \mathrm{ABA}: 100 \mathrm{mg} / \mathrm{l}\right.$, and control $\left.\left(\mathrm{Ctrl}_{\mathrm{h}}\right)\right]$, and 3 wheat (Triticum aestivum) cultivars [Gascogen $(\mathrm{G})$, Zagros $(\mathrm{Z})$ and Kuhdasht $(K)]$. The seeds were sterilized for 4 minutes in sodium hypochlorite $0.5 \%$, rinsed in distilled water and were placed at $23 \pm 1{ }^{\circ} \mathrm{C}$ in a germinator. Then, 
germinated seeds were sown in pots $(34 \mathrm{~cm}$ length, $25 \mathrm{~cm}$ width, and $18 \mathrm{~cm}$ height), which had sandy clay loam soil. Salt solutions (2.08 and $4.17 \mathrm{~g} / \mathrm{l}$ $\mathrm{NaCl}$, respectively) were poured on pots one week before planting, to reach 3.5 and $7 \mathrm{dS} / \mathrm{m}$ salinity levels. The initial salinity level (EC) of the soils in the pots was $3.93 \mathrm{dS} / \mathrm{m}$. The phytohormones were foliarly sprayed in three stages, including tillering, shooting and flag leaf appearance stage (FLAS).

\section{Membrane Stability (MS)}

MS was measured once before hormone spraying and another time at FLAS. For MS determination, the procedures of Khandan Bejandi et al. (2009) that is briefly mentioned here was followed, the fully expanded leaves at each stage were selected and onecentimetre pieces were cut from the middle of the leaves. Then, $0.3 \mathrm{~g}$ of the leaf samples were weighed and rinsed in distilled water. These pieces were put in tubes with $25 \mathrm{ml}$ distilled water and $25 \mathrm{ml}$ polyethylene glycol 40\% (PEG 6000) and then were put in an incubator for 24 hours $\left(10^{\circ} \mathrm{C}\right)$. After that time, the solution of tubes was poured out, and the pieces were rinsed. Then, control and treatment samples were put in $25 \mathrm{ml}$ distilled water for 24 hours. After a certain time, electrical conductivity of solutions was measured, and the samples were autoclaved for $15 \mathrm{~min}$, cooled down to room temperature and then measured once more. MS is defined as Eq. (1) according to Khandan Bejandi et al. (2009):

$\operatorname{CMS}[\%]=1-\left(1-\mathrm{T}_{1} / \mathrm{T}_{2}\right) /\left(1-\mathrm{C}_{1} / \mathrm{C}_{2}\right) \times 100$

In the above equation, $\mathrm{C}$ and $\mathrm{T}$ are the electrical conductivity for control and PEG treatment, respectively. Indices 1 and 2 are the first and second conductance, respectively.

\section{Chlorophyll Content (CC)}

$\mathrm{CC}$ was estimated at two stages, once before hormone spraying (4 leaves stage) and another time at FLAS by hand-held chlorophyll meter (SPAD-502, Minolta, Japan).

\section{Chlorophyll Fluorescence (CF)}

$\mathrm{CF}$ was measured after hormone spraying at FLAS by a chlorophyll fluorometer (Optiscience, USA).

\section{Stomatal Conductance (SC)}

SC was measured after hormone spraying at FLAS by porometer (Decagon, USA).

\section{Relative Water Content (RWC)}

RWC was estimated according to Khandan Bejandi et al. (2009) using the following equation:

$\mathrm{RWC}=\left(\mathrm{F}_{\mathrm{W}}-\mathrm{D}_{\mathrm{W}}\right) /\left(\mathrm{T}_{\mathrm{W}}-\mathrm{D}_{\mathrm{W}}\right) \times 100$

where $\mathrm{F}_{\mathrm{w}}, \mathrm{D}_{\mathrm{w}}$ and $\mathrm{T}_{\mathrm{w}}$ are the fresh, dry and turgid weight of leaves, respectively. Samples were taken from newly expanded leaves. Leaves were immediately weighed and then immersed in distilled water for 5 hours. Thereafter, turgid weight was obtained and finally, dry weight was measured 24 hours after being put at $75^{\circ} \mathrm{C}$ oven.

\section{Statistical Analysis}

After normalization test, the data were analyzed by SAS 9.1 and SPSS 16.0 software. Means were compared by Slice command in SAS at $1 \%$ statistical probability level.

\section{RESULTS AND DISCUSSION}

The results showed that interactions among cultivars, salinity, and hormones on the evaluated traits were significant (Table 1). Based on the interaction between hormones and salinity, $\mathrm{GA}_{3}$ decreased more inhibitory effects of salinity as compared to ABA (Table 2).

Before the hormone spraying, the highest MS was achieved in $\mathrm{K}$ and $\mathrm{Ctrl}_{\mathrm{s}}$ and the lowest value was obtained in $\mathrm{G}$ at $7 \mathrm{dS} / \mathrm{m}$ salinity level (Figure 1).

After the hormone spraying, the highest MS (about 20\%) was achieved in $\mathrm{K}$, without salinity and under $\mathrm{GA}_{3}$ treatment and the lowest MS was observed in G, without salinity and under ABA treatment. By spraying of $\mathrm{GA}_{3}$, MS was increased under control ( 0 ) and both salinity levels ( 3.5 and $7 \mathrm{dS} / \mathrm{m})$. Also, spraying of $\mathrm{ABA}$ in interaction with salinity levels increased MS as compared to $\mathrm{Ctrl}_{\mathrm{s}}$ and $\mathrm{Ctrl}_{\mathrm{h}}$, but this increase was less than the content resulted from spraying of $\mathrm{GA}_{3}$ (Table 2).

Tellingly, $\mathrm{GA}_{3}$ as compared to ABA showed more MS. However, interestingly enough, $\mathrm{GA}_{3}$ treatment under $\mathrm{Ctrl}_{\mathrm{s}}$ did not increase MS. By contrast, in G, $\mathrm{GA}_{3}$ treatment at 3.5 and $7 \mathrm{dS} / \mathrm{m}$ salinity levels, in 
comparison to Ctrls caused more decrease in MS as compared to the same condition for ABA. In $\mathrm{K}$ like $\mathrm{G}$ and contrary to $\mathrm{Z}, \mathrm{ABA}$ in 3.5 and $7 \mathrm{dS} / \mathrm{m}$ salinity as compared to $\mathrm{Ctrl}_{\mathrm{s}}$ was better than $\mathrm{GA}_{3}$ treatment. Ashraf et al. (2005) stated that membrane lipids stability under saline condition seldom remains intact. A major impact of environmental stress on plants is cellular membrane modification due to salt stress, expressed in increased permeability and leakage of ions (Khandan Bejandi et al. 2009). Studies showed that abiotic stresses, including salinity generated reactive oxygen species and membrane lipid peroxidation in leaves and ears of wheat (Beltrano et al. 1997), caused decrease in MS. Khandan Bejandi et

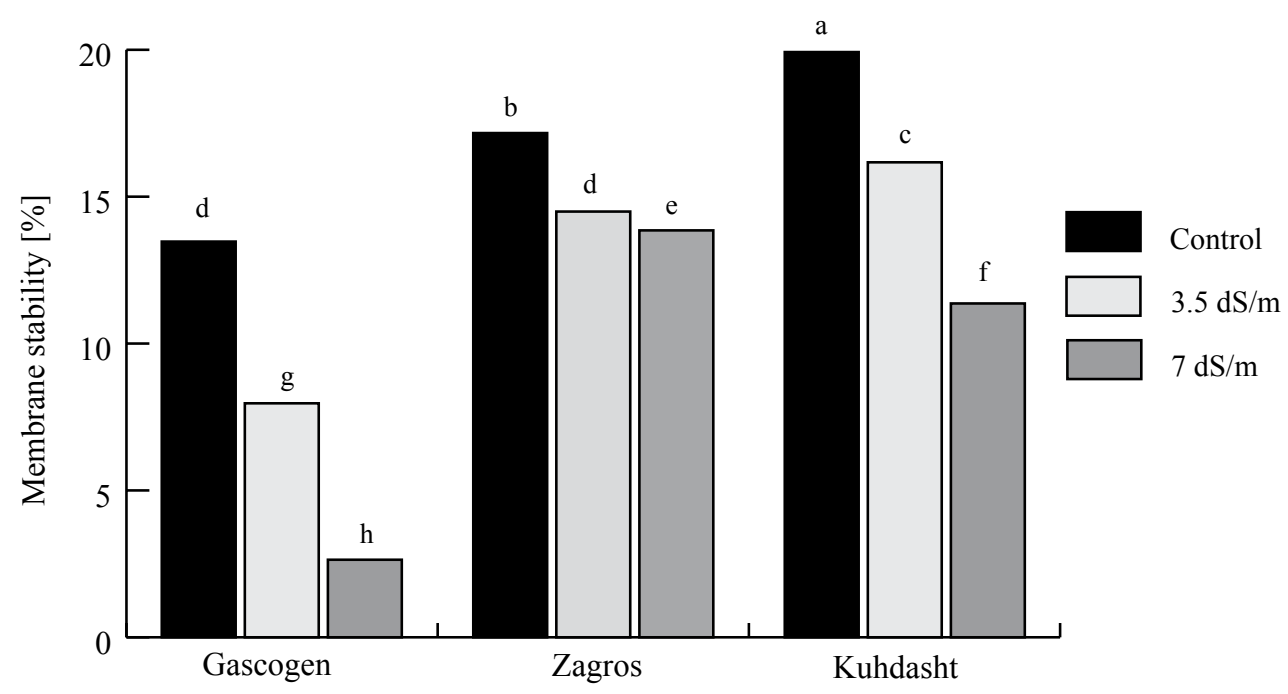

Figure 1. Membrane stability [\%] under salinity stress in the three wheat cultivars

$\begin{array}{llllllllllllll}\mathrm{T} & \mathrm{a} & \mathrm{b} & 1 & \mathrm{e} & 1\end{array}$

Analysis of variance for effects of cultivar, salinity and phytohormones on evaluated traits in wheat

\begin{tabular}{|l|c|c|c|c|c|c|}
\hline \multirow{2}{*}{ S.O.V } & \multirow{2}{*}{ df } & \multicolumn{5}{|c|}{ MS } \\
\cline { 3 - 7 } & & $\begin{array}{c}\text { Membrane } \\
\text { stability }\end{array}$ & $\begin{array}{c}\text { Chlorophyll } \\
\text { content }\end{array}$ & $\begin{array}{c}\text { Stomatal } \\
\text { conductance }\end{array}$ & $\begin{array}{c}\text { Chlorophyll } \\
\text { fluorescence }\end{array}$ & $\begin{array}{c}\text { Relative water } \\
\text { content }\end{array}$ \\
\hline Cultivar (C) & 2 & $2,638.021^{++}$ & $862.156^{++}$ & $576.411^{++}$ & $0.001^{++}$ & $2,839.828^{++}$ \\
Salinity (S) & 2 & $123.486^{++}$ & $162.443^{++}$ & $1,518.478^{++}$ & $0.001^{++}$ & $594.008^{++}$ \\
Hormone (H) & 2 & $109.446^{++}$ & $58.609^{++}$ & $1,789.296^{++}$ & $0.035^{++}$ & $816.332^{++}$ \\
$\mathrm{C} \times \mathrm{S}$ & 4 & $39.406^{++}$ & $12.108^{++}$ & $851.088^{++}$ & $0.001^{++}$ & $246.715^{++}$ \\
$\mathrm{C} \times \mathrm{H}$ & 4 & $15.156^{++}$ & $0.191^{+}$ & $215.310^{++}$ & $0.002^{++}$ & $23.098^{++}$ \\
$\mathrm{H} \times \mathrm{S}$ & 4 & $18.542^{++}$ & $0.074^{\mathrm{ns}}$ & $142.363^{++}$ & $0.001^{++}$ & $34.226^{++}$ \\
$\mathrm{C} \times \mathrm{S} \times \mathrm{H}$ & 8 & $13.668^{++}$ & $0.192^{++}$ & $40.494^{++}$ & $0.0001^{\mathrm{ns}}$ & $22.056^{++}$ \\
Error & 81 & 0.062 & 0.060 & 0.066 & 0.0001 & 0.333 \\
$\mathrm{CV}[\%]$ & & 0.32 & 0.55 & 0.53 & 0.88 & 1.28 \\
\hline
\end{tabular}

${ }^{+}$and ${ }^{++}$: Significant at $5 \%$ and $1 \%$ of probability levels, respectively; ${ }^{\text {ns: }}$ Non-significant 
al. (2009) stated that the accumulation of reactive oxygen species under stress conditions may damage many cell components, such as lipids, proteins, carbohydrates and nucleic acids as a result of cell membrane lipids peroxidation. The excess of $\mathrm{NaCl}$ leads to the loss of potassium due to membrane depolarization by sodium ions (Turan et al. 2009). Bhutta investigation (2011) showed that MS increased under the non-saline environment in the leaves of wheat seedlings, in so far as under low saline levels, MS decreased $22 \%$ and $29 \%$ after 20 and 40 days treatments, respectively. MS showed more decrease (27\%) under high saline levels (160 $\mathrm{nM} \mathrm{NaCl})$ after 40 days. In other words, MS in wheat leaves reached the lowest levels in both wheat genotypes (S24 and DN-27).



Mean comparison of interaction among variety $\times$ salinity $\times$ hormone with evaluated traits in wheat

\begin{tabular}{|c|c|c|c|c|c|c|c|}
\hline \multicolumn{3}{|c|}{ Treatment } & $\begin{array}{c}\text { Membrane } \\
\text { stability [\%] }\end{array}$ & $\begin{array}{c}\text { Chlorophyll } \\
\text { content }\end{array}$ & $\begin{array}{c}\text { Stomatal conduct } \\
{\left[\mathrm{mmol} / \mathrm{m}^{2} / \mathrm{s}\right]}\end{array}$ & $\begin{array}{l}\text { Chlorophyll } \\
\text { fluorescence }\end{array}$ & $\begin{array}{c}\text { Relative water } \\
\text { content }\end{array}$ \\
\hline \multirow{9}{*}{$\mathrm{S} 1$} & & H1 & $85.65^{\mathrm{b}}$ & $53.79^{\mathrm{b}}$ & $40.57^{\mathrm{e}}$ & $0.7100^{\mathrm{b}}$ & $84.97^{c}$ \\
\hline & G & $\mathrm{H} 2$ & $93.79^{\mathrm{a}}$ & $52.03^{\mathrm{c}}$ & $33.43^{\mathrm{f}}$ & $0.6733^{\mathrm{e}}$ & $83.50^{\mathrm{d}}$ \\
\hline & & $\mathrm{H} 3$ & $74.37^{\mathrm{e}}$ & $54.67^{\mathrm{a}}$ & $60.98^{\mathrm{a}}$ & $0.6900^{\mathrm{c}}$ & $87.49^{\mathrm{b}}$ \\
\hline & & $\mathrm{H} 1$ & $75.62^{\mathrm{d}}$ & $42.90^{\mathrm{e}}$ & $23.47^{\mathrm{h}}$ & $0.7100^{b}$ & $54.97^{\mathrm{h}}$ \\
\hline & Z & $\mathrm{H} 2$ & $77.00^{\mathrm{c}}$ & $41.04^{\mathrm{f}}$ & $16.25^{\mathrm{i}}$ & $0.6000^{g}$ & $50.77^{\mathrm{i}}$ \\
\hline & & $\mathrm{H} 3$ & $74.06^{\mathrm{e}}$ & $43.85^{\mathrm{d}}$ & $41.00^{\mathrm{d}}$ & $0.6833^{\mathrm{d}}$ & $57.55^{\mathrm{g}}$ \\
\hline & & H1 & $62.68^{\mathrm{g}}$ & $46.79^{\mathrm{h}}$ & $31.80^{\mathrm{g}}$ & $0.7267^{a}$ & $78.94^{\mathrm{e}}$ \\
\hline & K & $\mathrm{H} 2$ & $63.65^{\mathrm{f}}$ & $45.33^{\mathrm{i}}$ & $46.66^{c}$ & $0.6100^{f}$ & $69.66^{\mathrm{f}}$ \\
\hline & & H3 & $59.26^{\mathrm{h}}$ & $48.62^{g}$ & $52.40^{\mathrm{b}}$ & $0.6700^{\mathrm{e}}$ & $90.65^{\mathrm{a}}$ \\
\hline \multirow{9}{*}{ S2 } & & $\mathrm{H} 1$ & $85.94^{b}$ & $48.19^{b}$ & $77.34^{b}$ & $0.6800^{\mathrm{c}}$ & $87.60^{b}$ \\
\hline & G & $\mathrm{H} 2$ & $86.84^{\mathrm{a}}$ & $47.08^{c}$ & $46.08^{f}$ & $0.6433^{\mathrm{f}}$ & $77.78^{\mathrm{c}}$ \\
\hline & & $\mathrm{H} 3$ & $84.01^{\mathrm{c}}$ & $49.88^{a}$ & $79.88^{\mathrm{a}}$ & $0.6567^{\mathrm{e}}$ & $91.55^{\mathrm{a}}$ \\
\hline & & H1 & $84.42^{\mathrm{c}}$ & $38.87^{\mathrm{h}}$ & $56.46^{\mathrm{d}}$ & $0.6933^{b}$ & $67.06^{\mathrm{f}}$ \\
\hline & Z & $\mathrm{H} 2$ & $85.60^{\mathrm{b}}$ & $37.07^{\mathrm{i}}$ & $51.31^{\mathrm{e}}$ & $0.6367^{g}$ & $63.61^{\mathrm{g}}$ \\
\hline & & $\mathrm{H} 3$ & $82.99^{\mathrm{d}}$ & $39.84^{\mathrm{g}}$ & $60.25^{\mathrm{c}}$ & $0.6767^{\mathrm{d}}$ & $70.50^{\mathrm{e}}$ \\
\hline & & $\mathrm{H} 1$ & $63.68^{f}$ & $43.79^{\mathrm{e}}$ & $35.96^{\mathrm{h}}$ & $0.7067^{\mathrm{a}}$ & $67.11^{\mathrm{f}}$ \\
\hline & $\mathrm{K}$ & $\mathrm{H} 2$ & $64.43^{\mathrm{e}}$ & $42.14^{\mathrm{f}}$ & $31.30^{\mathrm{i}}$ & $0.6233^{\mathrm{h}}$ & $63.77^{\mathrm{g}}$ \\
\hline & & H3 & $61.46^{\mathrm{g}}$ & $45.62^{\mathrm{d}}$ & $37.97^{\mathrm{g}}$ & $0.6833^{\mathrm{c}}$ & $73.33^{\mathrm{d}}$ \\
\hline \multirow{9}{*}{$\mathrm{S} 3$} & & H1 & $87.42^{\mathrm{b}}$ & $50.91^{\mathrm{b}}$ & $55.45^{\mathrm{e}}$ & $0.7100^{\mathrm{a}}$ & $78.75^{\mathrm{b}}$ \\
\hline & G & $\mathrm{H} 2$ & $88.60^{\mathrm{a}}$ & $49.09^{c}$ & $36.08^{\mathrm{i}}$ & $0.6500^{\mathrm{f}}$ & $67.67^{\mathrm{d}}$ \\
\hline & & $\mathrm{H} 3$ & $85.26^{\mathrm{d}}$ & $51.77^{\mathrm{a}}$ & $70.01^{\mathrm{a}}$ & $0.6567^{\mathrm{e}}$ & $82.73^{a}$ \\
\hline & & H1 & $86.10^{\mathrm{c}}$ & $37.58^{\mathrm{h}}$ & $53.79^{f}$ & $0.6867^{\mathrm{c}}$ & $48.22^{\mathrm{h}}$ \\
\hline & Z & $\mathrm{H} 2$ & $87.27^{\mathrm{b}}$ & $36.01^{\mathrm{i}}$ & $46.19^{\mathrm{h}}$ & $0.6100^{\mathrm{h}}$ & $42.83^{\mathrm{i}}$ \\
\hline & & $\mathrm{H} 3$ & $83.99^{\mathrm{e}}$ & $39.15^{\mathrm{g}}$ & $64.96^{\mathrm{c}}$ & $0.6667^{\mathrm{d}}$ & $63.45^{\mathrm{e}}$ \\
\hline & & H1 & $64.16^{\mathrm{f}}$ & $41.85^{\mathrm{e}}$ & $58.41^{\mathrm{d}}$ & $0.7000^{\mathrm{b}}$ & $34.97^{\mathrm{f}}$ \\
\hline & $\mathrm{K}$ & $\mathrm{H} 2$ & $65.54^{\mathrm{g}}$ & $40.05^{\mathrm{f}}$ & $48.17^{\mathrm{g}}$ & $0.6333^{g}$ & $52.72^{\mathrm{g}}$ \\
\hline & & H3 & $63.31^{\mathrm{h}}$ & $42.89^{d}$ & $66.96^{\mathrm{b}}$ & $0.6667^{\mathrm{d}}$ & $73.22^{\mathrm{c}}$ \\
\hline
\end{tabular}

Similar letters in each column are not significant at $1 \%$ and $5 \%$ probability level

$\mathrm{S} 1=$ Control, $\mathrm{S} 2=3.5 \mathrm{dS} / \mathrm{m}$ salinity, $\mathrm{S} 3=7 \mathrm{dS} / \mathrm{m}$ salinity

$\mathrm{G}=$ Gascogen cultivar, $\mathrm{K}=$ Kuhdasht cultivar, $\mathrm{Z}=$ Zagros cultivar, $\mathrm{H} 1=$ control, $\mathrm{H} 2=\mathrm{Abscisic}$ acid, $\mathrm{H} 3=$ Gibberellic acid 
Before hormone spraying, with increase in salinity, significant reduction in $\mathrm{CC}$ was observed and the highest reduction reached $25.06 \%$ in $\mathrm{Z}$ at $3.5 \mathrm{dS} / \mathrm{m}$ salinity (Figure 2). After hormone spraying, the highest $\mathrm{CC}$ was obtained under $\mathrm{GA}_{3}$ treatment (Table 2). It seems that $\mathrm{GA}_{3}$ has an important effect on Chl stability and synthesis, even under salinity condition.

Reduction in leaf $\mathrm{CC}$ under $\mathrm{NaCl}$ stress is attributed to the destruction of $\mathrm{Chl}$ pigments and the instability of the pigment protein complex (Levitt 1980). The Chl depletion may be a result of inhibition of Chl biosynthesis. This inhibition is due to an increase in ethylene production by the elevated $\mathrm{NaCl}$ content (Khan 2003). Reduction in Chl concentrations is probably because of the inhibitory effect of the accumulated ions of various salts on the biosynthesis of different $\mathrm{Chl}$ fractions. Also, decrease in CC may be based on the formation of proteolytic enzymes such as chlorophyllase, which is responsible for the Chl degradation (Levent Tuna et al. 2008). It has also been shown that $\mathrm{GA}_{3}$ alleviates the effects of salt stress on pigments (Shah 2007). This may well be attributed to the $\mathrm{GA}_{3}$-generated enhancement of ultra-structural morphogenesis of plastids coupled with retention of $\mathrm{Chl}$ and delay of senescence caused by the hormone treatment (Shah 2007). Decrease in CC under salinity stress can be for this reason which $\mathrm{Chl}$ degradation is more than Chl synthesis (Uzma \& Asghari 2006). Sairam et al. (2002) reported that reduction of CC in a tolerant wheat variety was lower than in a sensitive one. Akbari Ghogdi et al. (2012) documented that salt treatment reduced the $\mathrm{CC}$ at tillering stage and decreased it at flowering stage in wheat cultivars.

In the present experiment, $\mathrm{ABA}$ caused the lowest $\mathrm{CF}$ in salinity levels. However, with scrutiny comparison of $\mathrm{GA}_{3}$ and $\mathrm{ABA}$, it can be understood that $\mathrm{ABA}$ in higher salinity levels caused much less decrement. The ratio $F_{v} / F_{m}$ is proportional in order to show maximum amount of PSII. The ratio for a functional leaf varies between 0.75 and 0.85 and a decline in this ratio is an indicator for photoinhibitory damage (DeEll et al. 1999).

There was a significant increase in SC with spraying of $\mathrm{GA}_{3}$ under saline condition in comparison to the $\mathrm{Ctrl}$ s condition. The lowest amount of $\mathrm{SC}$ was achieved in $\mathrm{Z}$ under ABA treatment and the $\mathrm{Ctrl}_{\mathrm{s}}$ (Table 2). Interaction between ABA and salinity probably decreases SC to the lower amount than that of control. In brief, in the three cultivars $\mathrm{G}, \mathrm{K}$ and $\mathrm{Z}$ and salinity levels, ABA as compared

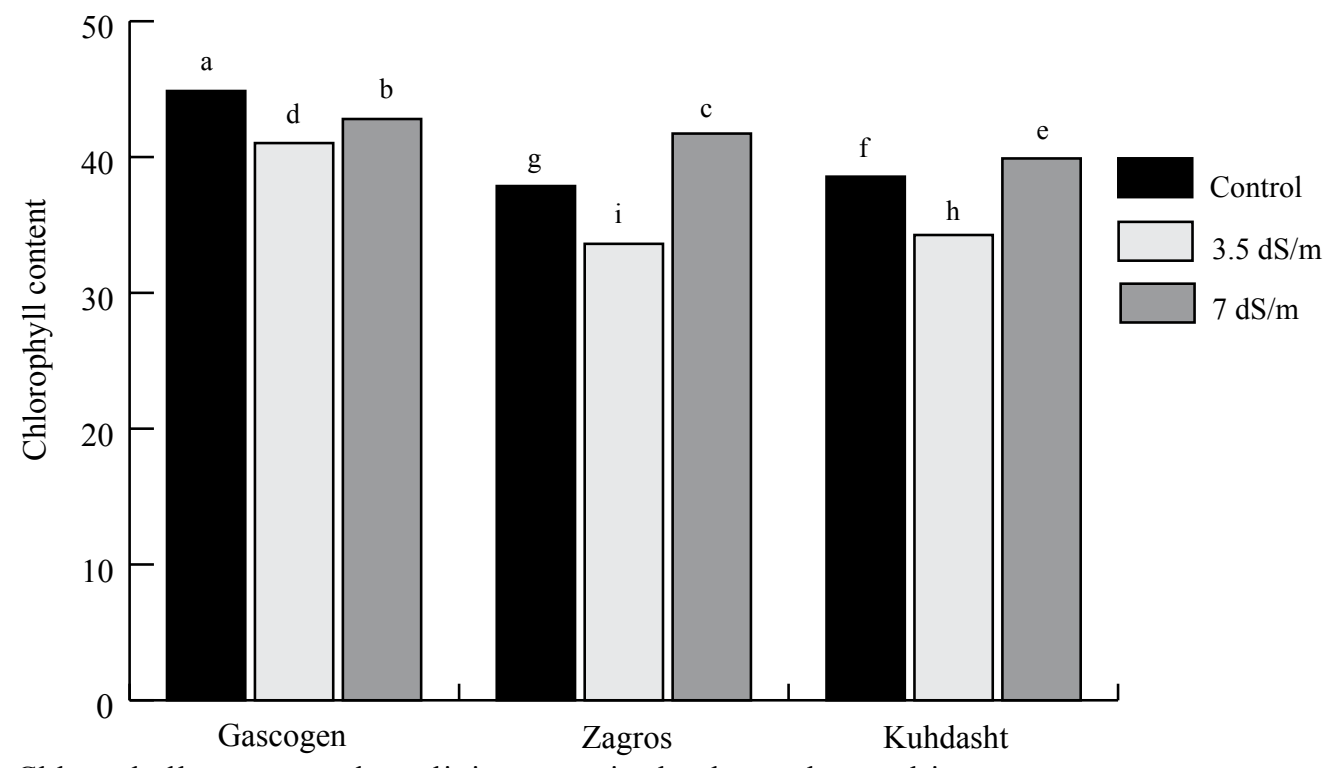

Figure 2. Chlorophyll content under salinity stress in the three wheat cultivars 
to $\mathrm{GA}_{3}$, decreased SC. Environmental factors such as salinity that affect water quality lead to changes in stomatal opening (Nelson et al. 1998). Salinity increases stomatal resistance, which could be explained by inhibition of plant growth due to water stress (Chatrath et al. 2000). To control the water status of stomatal pore, plants may use two hormone mediated strategies: 1) is to control stomatal pore width, and 2) is to control the hydraulic conductivity of the root (Ludewig et al. 1988). ABA in guard cells activates ionic channels and proton pump that are associated with stomatal closure (Goh et al. 2009). $\mathrm{H}_{2} \mathrm{O}_{2}$ acts as a local or systemic signal for leaf stomata closure (Chaves et al. 2009). Decrease in SC indicates that changes in the osmotic situation of root medium quickly affect shoot water relations (Rodriguez et al. 1997). Salinity causes ABA production in roots which is translocated to shoot and induces stomatal closure and limitation of cell growth (Lobna et al. 2009). Rahnama et al. (2010) reported that salinity reduced SC in different wheat genotypes and the largest reduction was observed in sensitive genotypes of wheat. Also, they suggested that root signals presumably cause a large decrease in SC of wheat genotypes under salinity.

ABA in $\mathrm{Ctrl}_{\mathrm{s}}$ reduced RWC. However, interaction between $\mathrm{GA}_{3}$ and salinity levels increased the content of RWC (Table 2). RWC decreased by increase in salinity levels in wheat genotypes (Akbari Ghogdi et al. 2012). It seems that decrease in RWC decreases the turgor due to water limitation. Such an increase in the RWC of salinized plants over that of the control or hormone-treated salinized plants may be due to the accumulation of ABA to levels that cause stomatal closure, which reduces water loss, maintains turgor and improves the water use efficiency of plants and allows more growth with a given supply of water (Aldesuquy \& Ibrahim 2001).

Generally, it is expected that $\mathrm{GA}_{3}$ moderates the deleterious condition of saline stress in comparison to ABA in wheat. It is known that conduction of the present study in field is essential in order to assess effects of the factors in uncontrollable condition. However, in natural condition there are many factors that are out of control, thus the results of in $n a-$ tura studies may deviate from those of greenhouse condition. It is recommended to evaluate the factors of the present greenhouse study in field.

\section{CONCLUSION}

According to the present experiment, hormones and high saline levels have different effects on various parameters in wheat cultivars. High saline levels cause higher chlorophyll fluorescence, and relative water content. In contrast, lower membrane stability, chlorophyll content, and stomatal conductance have been caused under saline condition. Abscisic acid is more effective for decreasing adverse consequences of salinity on chlorophyll fluorescence, membrane stability and, relative water content. However, gibberellic acid has beneficial influence on chlorophyll content and stomatal conductance as compared by abscisic acid under saline stress. In sum, phytohormones play a significant role in moderating the effects of salinity on photosynthetic traits and membrane stability.

Acknowledgments. The authors thank Prof. M. Pessarakli, Research Professor (School of Plant Sciences, College of Agriculture and Life Sciences, The University of Arizona, Tucson, Arizona, USA) for helpful discussions and advice. This research was supported by an MSc grant from The University of Mohaghegh Ardabili, Iran, Ardabil.

\section{REFERENCES}

ABDEL-HALEEM, H.A. - TANIMOTO, S. 2008. ABA-induced polypeptide accumulation in drought tolerant rice. In Bulletin of Faculty of Agriculture Saga University, vol. 93, 2008, pp. 109-115.

ADNAN SHAHID, M. - PERVEZ, M.A. - BALAL, R.M. - Azhar, N. - SHAHZAD, J. 2008. Physiological responses of pea (Pisum sativum cv. Meteor) to irrigation salinity. In Pakistan Journal of Agricultural Sciences, vol. 45, 2008, pp. 36-39.

AKBARI GHOGDI, E. - IZADI-DARBANDI, A. - BORZOUEI, A. 2012. Effects of salinity on some physiological traits in wheat (Triticum aestivum L.) cultivars. In Indian Journal of Science and Technology, vol. 5, 2012, no. 1, pp. 1901-1906.

ALDESUQUY, H.S. - GABER, A.M. 1993. Effect of growth regulators on vicia faba plants irrigated by seawater, leaf area, pigment content and photosynthetic activity. In Plant Biology, Vol. 35, 1993, pp. 519-527. DOI: 10.1007/BF02928026

ALDESUQUY, H.S. - IBRAHIM, A.H. 2001. Water relations, abscisic acid and yield of wheat plants in relation to the interactive effect of Seawater and growth bioregulators. In Journal of Agrono- 
my and Crop Science. vol. 187, 2001, pp. 97-104. DOI: $10.1046 / j .1439-037 X .2001 .00506 . x$

ALLAHVERDIEV, S. R. - MAVITUNA, M. - GANIEVA, R. - NAFISI, S. 1998. Effects of salt stress and synthetic hormone polystimuline $\mathrm{k}$ on photosynthetic activity of Trianea bogotensis karst. In Turkish Journal of Botany, vol. 22, 1998, pp. 19-23.

ASHRAF, M.Y. - AKHTAR, K. - SARWAR, G. ASHRAF, M. 2005. Role of rooting system in salt tolerance potential of different guar accessions. In Agronomy for Sustainable Development, vol. 25, 2005, pp. 243-249. DOI: 10.1051/agro:2005019

BELKHODJA, R. - MORALES, F. - ABADIA, A. - MEDRANO, H. - ABADIA, J. 1999. Effects of salinity on chlorophyll fluorescence and photosynthesis of barley (Hordeum vulgare L.) grown under a tripleline-source sprinkler system in the field. In Photosynthe-tica, vol. 36, 1999, no. 3, pp. 375-387. DOI: 10.1023/A:1007019918225

BELTRANO, J. - MONTALDI, E. - BARTOLI, C. - CARBONE, A. 1997. Emission of water stress ethylene in wheat (Triticum aestivum L.) ears: Effects of rewatering. In Plant Growth Regulation, vol. 21, 1997, pp. 121-126. DOI: 10.1023/A:1005717820782

BHUTTA, W.M. 2011. Antioxidant activity of enzymatic system of two different wheat (Triticum aestivum L.) cultivars growing under salt stress. In Plant Soil Environment, vol. 57, 2011, no. 3, pp. 101-107.

CHAKRABARTI, N. - MUKHERJI, S. 2003. Alleviation of $\mathrm{NaCl}$ stress by pre-treatment with phytohormones in Vigna radiata. In Plant Biology, vol. 46, 2003, pp. 589-594. DOI: 10.1023/A:1024827931134

CHATRATH, A.-MANDAL, P.K. - ANURADHA, M. 2000. Effect of secondary salinization on photosynthesis in fodder oat (Avena sativa L.) genotypes. In Journal of Agronomy and Crop Science, vol. 184, 2000, pp. 13-16. DOI: $10.1046 / \mathrm{j} .1439-037 x .2000 .00333 . \mathrm{x}$

CHAVES, M.M. - FLEXAS, J. - PINHEIRO, C. 2009 Photosynthesis under drought and salt stress: regulation mechanisms from whole plant to cell. In $\mathrm{An}$ nals of Botany, vol. 103, 2009, pp. 551-560. DOI: $10.1093 / \mathrm{aob} / \mathrm{men} 125$

DeELL, J.R. - VAN COOTEN, O. - PRANGE, R.K. - MURR, D.P. 1999. Applications of chlorophyll fluorescence techniques in postharvest physiology. In Horticultural Reviews, vol. 23, 1999, pp. 69-107. DOI: 10.1002/9780470650752.ch2

EL-BASSIOUNY, H.M.S. - BEKHETA, M.A. 2004. Role of putrescine on growth, regulation of stomatal aperture, ionic contents and yield by two wheat cultivars under salinity stress. In Egyptian Journal of Physiology Science, vol. 26, 2004, pp. 95-114.

EL-TAYEB, M.A. 2005. Response of barley grains to the interactive effect of salinity and salicylic acid. In Journal of Plant Growth Regulation, vol. 45, 2005, pp. 215-224. DOI: 10.1007/s 10725-005-4928-1

ESFANDIARI, E. - SHEKARI, F. - SHEKARI, F. - ESFANDIARI, M. 2007. The effect of salt stress on antioxidant enzymes' activity and lipid peroxidation on the wheat seedling. In Notulae Botanicae Horti Agrobotanici ClujNapoca, vol. 35, 2007, pp. 48-56.
GOH, C.H. - LEE, D.J. - BAE, H.J. 2009. Gibberellic acid of Arabidopsis regulates the abscisic acid-induced inhibition of stomatal opening in response to light. In Plant Science, vol. 176, 2009, no. 1, pp. 136-142. DOI: $10.1016 /$ j.plantsci.2008.10.005

GONZÁLEZ, L. - GONZÁLEZ-VILAR, M. 2001. Determination of relative water content, In REIGOSA ROGER, M.G. (Ed.): Handbook of Plant Ecophysiology Techniques, the Netherlands : Kluwer Academic Publishers, 2001. ISBN 978-0-7923-7053-6, pp 207-212.

GUPTA, S. - CHATTOPADHYAY, P. - GHOSH, B. - SEN GUPTA, D.N. 1998. Expression of abscisic acid-responsive element-binding protein in salt-tolerant indica rice (Oryza sativa L. cv. Pokkali). In Plant Molecular Biology, vol. 37, 1998, pp. 629-637. DOI: 10.1023/ A:1005934200545

IQBAL, N. - ASHRAF, M.Y. - JAVED, F. - MARTINEZ, V. - AHMAD, K. 2006. Nitrate reduction and nutrient accumulation in wheat (Triticum aestivum L.) grown in soil salinization with four different salts. In Journal of Plant Nutrition, vol. 29, 2006, pp. 409-421. DOI: $10.1080 / 01904160500524852$

JYOTHSNAKUMARI, G. - THIPPESWAMY, M. - VEERANAGAMALLALAH, G. - SUDHAKAR, G. 2009. Differential expression of LEA proteins in two genotypes of mulberry under salinity. In Biologia Plantarum, vol. 53, 2009, no. 1, pp. 145-150. DOI: $10.1007 /$ s10535-009-0022-2

KAYA, C. - TUNA, A.L. - YOKAS, I. 2009. The role of plant hormones in plants under salinity stress. In ASHRAF, M. (Ed.) OZTURK, M. ATHAR, HR. Salinity and water stress: improving crop efficiency. Tasks for vegetation sciences 34, vol. 44. Springer science, 2009. pp 45-49. DOI: 10.1007/978-1-4020-9065-3_5

KHAN, N.A. 2003. NaCl inhibited chlorophyll synthesis and associated changes in ethylene evolution and antioxidative enzymes activities in wheat. In Journal of Plant Biology, vol. 47, 2003, pp. 437-440. DOI: 10.1023/B:BIOP.0000023890.01126.43

KHANDAN BEJANDI, T. - SEDGHI, M. - SEYED SHARIFI, R. - NAMVAR, A. - MOLAEI, P. 2009. Seed priming and sulfur effects on soybean cell membrane stability and yield in saline soil. Pesquisa Agropecuária Brasileira, vol. 44, 2009, pp. 1114-1117. DOI: 10.1590/ S0100-204X2009000900007

KRISHNARAJ, S. - MAWSON, B.T. - YEUNG, E.C. - THORPE, T.A. 1993. Utilization of induction and quenching kinetics of chlorophyll a fluorescence for in vivo salinity screening studies in wheat (Triticum aestivum vars. Kharchia-65 and Fielder). In Canadian Journal of Botany, vol. 71, 1993, pp. 87-92. DOI: 10.1139/ b93-010

LEVENT TUNA, A. - KAYA, C. - DICILITAS, M. - HIGGS, D. 2008. The combined effects of gibberellic acid and salinity on some antioxidant enzyme activities, plant growth parameters and nutritional status in maize plants. In Environmental and Experimental Botany, vol. 62, 2008, pp. 1-9. DOI: 10.1016/ j.envexpbot.2007.06.007

LEVITT, J. 1980. Responses of Plants to Environmental Stresses: Water, radiation, salt, and other stress- 
es. New York, USA : Academic Press, 1980. 607 pp. ISBN 978-0124455023.

LOBNA, Z. - GHARBI, F. - REZGUI, F. - REJEB, S. NAHDI, H. - REJEB, M. N. 2009. Application of chlorophyll fluorescence for the diagnosis of salt stress in tomato (Solanum lycopersicum) (variety Rio Grande). In Scientia Horticulturae, vol. 120, 2009, pp. 367-372. DOI: $10.1016 /$ j.scienta.2008.11.025

LUDEWIG, M. - DORFFLING, K. - SEIFERT, H. 1988. Abscisic acid and water transport in sunflowers. In Planta, vol. 175,1988 , pp. $325-333$. DOI: $10.1007 /$ BF00396337

MUNNS, R. 2005. Genes and salt tolerance: bringing them together. In New Phytologist, vol. 167, 2005, pp. 645-663. DOI: 10.1111/j.1469-8137.2005.01487.x

MUNNS, R. - TERMAAT, A. 1986. Whole plant responses to salinity. In Australian Journal of Plant Physiology, vol. 13, 1986, pp. 143-160. DOI: 10.1071/PP9860143

NAQVI SSM. 1999. Plant hormones and stress phenomena. In PESSARAKLI, M. ed, Handbook of plant and crop stress, Marcel Dakker, New York, pp. 709-730. DOI: $10.1201 / 9780824746728 . c h 34$

NELSON, D.E. - RAMMESMAYER, G. - BOHNERT, H.J. 1998. Regulation of cell-specific inositol metabolism and transport in plant salinity tolerance. In The Plant Cell, vol. 10, 1998, no. 5, pp. 753-764. DOI: 10.1105/ tpc. 10.5.753

PRAKASH, L. - PRATHAPASENAN, G. 1990. Interactive effect of $\mathrm{NaCl}$ salinity and gibberellic acid on shoot growth, content of abscisic acid and gibberellinslike substances and yield of rice (Oryza sativa L. var GR-3). In Plant Science, vol. 100, 1990, pp. 173-181. DOI: $10.1007 / \mathrm{BF} 03053447$

RAHNAMA, H. - EBRAHIMZADEH, H. 2004. The effect of $\mathrm{NaCl}$ on proline accumulation in potato seedling and calli. In Physiologia Plantarum, vol. 26, 2004, no. 3, pp. 263-270. DOI: 10.1007/s11738-004-0016-9

RAHNAMA, A. - POUSTINI, K. - TAVAKKOL-AF-
SHARI, R. - TAVAKOLI, A. 2010. Growth and stomatal responses of bread wheat genotypes in tolerance to salt stress. In International Journal of Biological and Life Sciences, vol. 6, 2010 , pp. 4.

RODRIGUEZ, P. - DELL'AMICO, J. - MORALES, D. - SANCHEZ BLANCO, M.J. 1997. Effects of salinity on growth, shoot water relations and root hydraulic conductivity in tomato plants. In The Journal of Agricultural Science, vol. 128, 1997, pp. 439-444.

SAIRAM, R.K. - VEERABHADRA RAO, K. - SRIVASTAVA, G.C. 2002. Differential response of wheat genotypes to long term salinity stress in relation to oxidative stress, antioxidant activity and osmolyte concentration. In Plant Science, vol. 163, 2002, pp. 1037-1046. DOI: $10.1016 / \mathrm{S} 0168-9452(02) 00278-9$

SAYED, O.H. 2003. Chlorophyll fluorescence as a tool in cereal crop research. In Photosynthetica, vol. 41, 2003, pp. 321-330. DOI: 10.1023/B:PHOT.0000015454.36367. e2

SCHONFELD, M.A. - JOHNSON, R.C. - CARVER, B.F. - MORNHINWEG, D.W. 1988. Water relations in winter wheat as drought resistance indicators. In Journal of Crop Science, vol. 28, 1988, pp. 526-531. DOI: $10.2135 /$ cropsci1988.0011183X002800030021x

SHAH, S.H. 2007. Effects of salt stress on mustard as affected by gibberellic acid application. In General and Applied Plant Physiology, vol. 33, 2007, pp. 97-106.

TURAN, M.A. - ELKARIM, A.H.A. - TABAN, N. TABAN, S. 2009. Effect of salt stress on growth, stomatal resistance, proline and chlorophyll concentrations on maize plant. In African Journal of Agricultural Research, vol. 4, 2009, no. 9, pp. 893-897.

UZMA, F. - ASGHARI, B. 2006. Effect of abscisic acid and chlorocholine chloride on nodulation and biochemical content of Vigna radiata (L.) under water stress. In Pakistan Journal of Botany, vol. 38, 2006, no. 5, pp. 1511-1518.

Received: October 17th, 2012 